\title{
NFKB2 Gene Rearrangement
}

National Cancer Institute

\section{Source}

National Cancer Institute. NFKB2 Gene Rearrangement. NCI Thesaurus. Code C136625.

A molecular abnormality indicating rearrangement of the NFKB2 gene. 